\title{
SISTEM PENDUKUNG KEPUTUSAN METODE ELECTRE PADA BAURAN PEMASARAN (7P) DALAM MEMULAI USAHA JASA CENTER
}

\author{
Sutrisno ${ }^{1}$, Agus Darmawan ${ }^{2}$, Fanisya Alva Mustika ${ }^{3}$ \\ Program Studi Informatika, Universitas Indraprasta PGRI \\ sutrisno3831@gmail.com ${ }^{1}$, agus.darmawan@ymail.com ${ }^{2}$, alva.mustika@gmail.com ${ }^{3}$
}

\begin{abstract}
Abstrak
Ketika memulai membuka usaha, banyak dari calon pengusaha yang menjadikan modal sebagai penghambat karena merasa tidak memiliki modal yang cukup. Padahal sebenarnya, untuk menjalankan usaha, modal yang paling penting adalah modal non-materi seperti ilmu manajemen pemasaran dengan teori bauran pemasaran (marketing mix). Alat pemasaran tersebut dikenal dengan istilah "4P" dan dikembangkan menjadi "7P" , yaitu : Produk (product), Harga (price), Tempat/distribusi (place), Promosi (promotion), Orang (people), Bukti fisik (physical evidence) dan Proses (process). Berdasarkan permasalahan tersebut dilakukan penelitian untuk merancang sistem pendukung keputusan yang bertujuan untuk membantu calon pengusaha dalam menentukan jenis usaha berdasarkan kriteria 7P. Metode yang digunakan dalam penelitian ini adalah metode Electre (Elimination and Choice Translation Reality). Hasil dari penelitian ini berupa sistem pendukung keputusan penentuan jenis usaha berdasarkan tujuh kriteria (7P) dalam menentukan jenis usaha.
\end{abstract}

Kata Kunci : Usaha, Jasa, Electre, Pemasaran.

Abstract
When starting a business, many prospective entrepreneurs find the capital an obstacle because they think that they do not have enough capital. In fact, to run a business, the most important capital is a non-material capital such as marketing management science with marketing mix theories. The marketing tool is known as "4P" and developed into "7P", namely: Product, Price, Placel Distribution, Promotion, People, Physical Evidence and Process. Based on these problems, a research is conducted to design a decision support system that helps to assist prospective entrepreneurs in determining the type of business based on $7 P$ criteria. The method used in this research is Electre (Elimination and Choice Translation Reality) method. The result of this research is a decision support system of determining the type of business based on seven criteria $(7 P)$ in determining the type of business.

Keywords: Business, Services, Electre, Marketing.

\section{PENDAHULUAN}

Saat ini tren wirausaha sedang naik daun di tengah masyarakat. Ketika memulai membuka usaha, banyak dari calon pengusaha yang menjadikan modal sebagai penghambat karena merasa tidak memiliki modal yang cukup. Padahal sebenarnya, untuk menjalankan usaha modal yang paling penting adalah modal non-materi seperti ilmu manajemen pemasaran dengan teori bauran pemasaran. Pada referensi [1] Mc Carthy mengklarifikasi alat pemasaran itu menjadi 4 kelompok yang disebut dengan 4P dalam pemasaran yaitu: produk (product), harga (price), tempat (place), dan promosi (promotion). Sementara pemasaran jasa diperlukan bauran pemasaran yang diperluas dengan penambahan unsur yang telah berkembang. Pemasaran jasa dikatakan sebagai salah satu bentuk produk yang berarti setiap tindakan atau perbuatan yang ditawarkan dari satu pihak ke pihak lainnya dan bersifat tidak berwujud. Sedangkan alat pemasaran tersebut dikenal dengan istilah " $4 \mathrm{P}$ " dan dikembangkan menjadi "7P" yang dipakai sangat tepat untuk pemasaran 
jasa yaitu : Produk (product), Harga (price), Tempat/distribusi (place), Promosi (promotion), Orang (people), Bukti fisik (physical evidence) dan Proses (process).

Sistem pendukung keputusan (SPK) merupakan informasi interaktif yang menyediakan informasi, pemodelan dan pemanipulasian data. Sistem itu digunakan untuk membantu pengambilan keputusan dalam situasi yang semi terstruktur dan situasi yang tidak terstruktur, dimana tidak seorang pun tahu secara pasti bagaimana keputusan seharusnya dibuat [2].

Pengambilan keputusan pada dasarnya adalah suatu bentuk pemilihan berbagai alternatif tindakan yang mungkin dipilih. Yang prosesnya melalui suatu mekanisme tertentu dengan harapan dapat menghasilkan keputusan terbaik sesuai kriteria yang digunakan. Salah satu metode pengambilan keputusan adalah metode electre.

Electre (Elimination Et Choix Traduisant La Realite) merupakan salah satu metode pengambilan keputusan multikriteria berdasarkan pada konsep outrangking dengan membandingkan pasangan alternatif-alternatif berdasarkan setiap kriteria yang sesuai [3]. Langkah- langkah yang dilakukan dalam penyelesaian masalah menggunakan metode electre adalah sebagai berikut:

1. Normalisasi matriks keputusan.

2. Pembobotan pada matriks yang telah dinormalisasi

3. Menentukan himpunan concordance dan discordance index.

4. Matriks concordance dan discordance.

5. Menentukan matriks dominan concordance dan discordance

6. Menentukan aggregate dominance matrix

7. Eliminasi alternatif yang less favourable.
Bahasa Java merupakan bahasa akhir abad 20 diciptakan Sun Microsystem pada tahun 1995. Bahasa java adalah bahasa modern yang diterima masyarakat komputasi dunia. Java tidak memiliki syarat untuk platform tertentu sehingga aplikasi dapat dijalankan di beragam platform termasuk platform Microsoft [4].

\section{METODE PENELITIAN}

\section{A. Studi lapangan}

Merupakan studi yang dilakukan penulis secara langsung ke lapangan dalam memperoleh sumber data.

\section{B. Studi kepustakaan (Library Study)}

Merupakan metode yang dilakukan penulis untuk mengumpulkan data-data yang bersifat teoritis dengan cara membaca buku, mata kuliah, dan tulisan lainnya.

\section{Pengumpulan Data}

Observasi, yaitu mendapatkan langsung dalam pengamatan sistem yang berjalan dan Kuisionier, yaitu penulis langsung memberikan kertas kuisionier ke pada wirausaha.

\section{Perancangan}

Dalam fase ini akan dibuat rancangan langkah kerja dari sistem secara menyeluruh, baik dari segi model maupun dari segi arsitektur untuk mempermudah implementasi dan pengujian.

\section{E. Implementasi}

Perancangan sistem didasarkan pada tahap pengumpulan data dan analisa kebutuhan yang telah dilakukan. Perancangan sistem menjelaskan desain metode Electre sebegai metode untuk proses memulai usaha jasa. Metode Electre merupakan salah satu metode pengambilan keputusan multikriteria dengan konsep ranking dengan menggunakan perbandingan berpasangan dari alternatif-alternatif berdasarkan setiap criteria yang sesuai Proses perhitungan dimulai dengan inputan jumlah dan jenis usaha dari user yang kemudian akan dihitung dengan 
menggunakan metode Electre hingga menghasilkan kelompok relevan yang sesuai kriteria yaitu jenis usaha yang terbaik. Berikut ditunjukkan Berikut ini merupakan langkah-langkah yang dilakukan dalam perhitungan Electre:

1. Ambil data alternatif

2. Ambil nilai bobot tiap kriteria

3. Menghitung matriks ternormalisasi.

4. Menghitung matriks normalisasi terbobot.

5. Menentukan himpunan concordance dan discordance.

6. Menentukan matriks concordance dan discordance.

7. Menentukan matriks domain concordance dan discordance.

8. Menentukan aggregate domainance matrix

9. Eliminasi alternatif less favourable

10.Pengambilan Keputusan.

\section{HASIL DAN PEMBAHASAN}

\section{A. Langkah Penyelesaian Masalah dengan metode Electre}

Penelitian yang dilakukan pada usaha jasa di kota Jakarta dalam melakukan penilaian dan perankingan berdasarkan kelebihan dan kekurangan masing-masing alternatif usaha jasa pada kriteria-kriteria Faktor "7P" dengan menggunakan metode Electre. Langkah-langkah penyelesaian menggunakan metode Electre :

1. Menentukan permasalahan, kriteria, dan alternative serta rating kecocokan

Permasalahan : Menentukan alternative jenis usaha terbaik untuk calon pengusaha menggunakan bauran pemasaran $7 \mathrm{P}$.

Kriteria : 7P (Product, People, Price, Promotion, Place, Physical, Process).

Alternatif : Alternatif-alternatif pilihan jenis usaha calon pengusaha.

Rating kecocokan : setiap alternative pada setiap kriteria akan dinilai dengan 1 sampai 5, dengan ketentuan :
1 : Sangat Buruk

2: Buruk

3 : Cukup

4 : Baik

5 : Sangat Baik

Bobot Preferensi :

tingkat kepentingan yang nantinya akan dijadikan bobot preferensi setiap kriteria juga dinilai dengan 1 sampai 5, dengan ketentuan:

1 : Sangat Rendah

2 : Rendah

3 : Cukup

4 : Tinggi

5 : Sangat Tinggi

2. Menentukan data alternative

Setiap nilai yang diberikan pada setiap alternatif di setiap kriteria merupakan nilai kecocokkan dimana nilai terbesar adalah terbaik, maka semua kriteria yang diberikan diasumsikan sebagai kriteria keuntungan.

3. Menentukan nilai bobot setiap kriteria Pengambil keputusan memberikan bobot preferensi

4. Menghitung matriks ternormalisasi

5. Menghitung matriks normalisasi terbobot

6. Menentukan himpunan concordance dan discordance

7. Menentukan matriks concordance dan discordance

8. Menentukan matriks domain concordance dan discordance

9. Menentukan aggregate domainance matrix

10. Eliminasi alternatif less favourable

\section{B. Algoritma Penyelesaian Masalah dengan Flowchart dan Pseudocode}

Tujuan dari pembangunan sistem pengambil keputusan ini yaitu dapat membantu dalam menyelesaikan masalah dalam menentukan prioritas alternatif . 


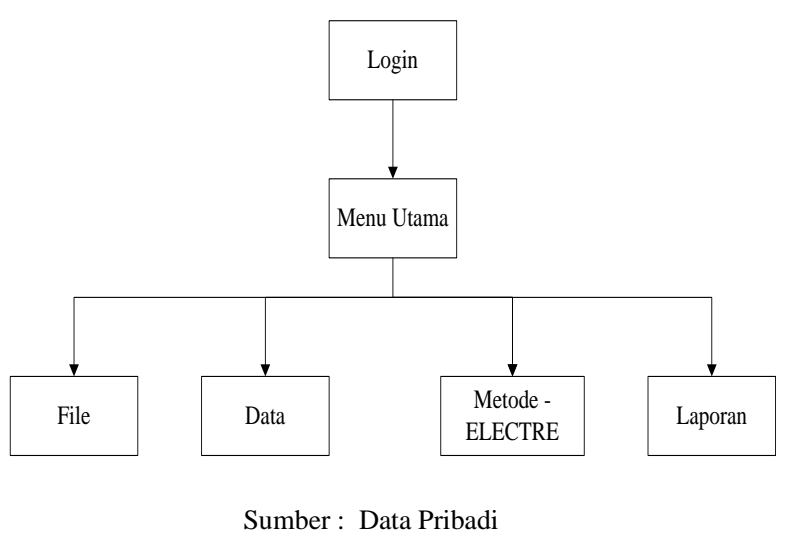

Gambar 1. Struktur Program

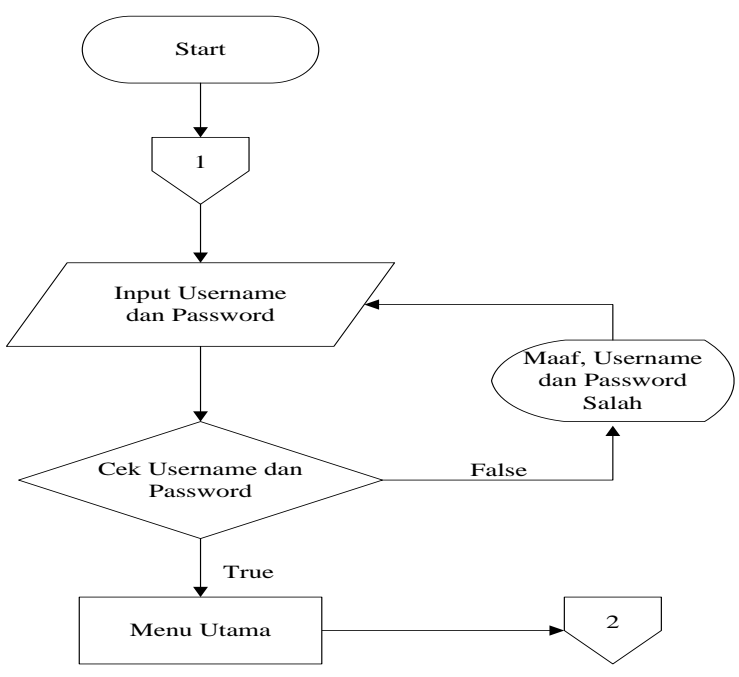

Sumber : Data Pribadi

Gambar 2. Flowchart Login

Pseudocode :

Jalankan sistem $=$ Tampilkan menu Login

If login berhasil maka

Tampilkan "Menu Utama"

Else maka

Tampilkan pesan "Maaf, Username dan Password Salah"

End Do

menu "Login"

Pada halaman login ini admin diharuskan mengisi Username dan Password yang sesuai dengan data dalam database agar dapat masuk ke menu utama. Halaman ini berfungsi sebagai fasilitas keamanan atas data penting yang ada pada menu utama, sehingga hanya admin saja yang bisa mengelola data tersebut.

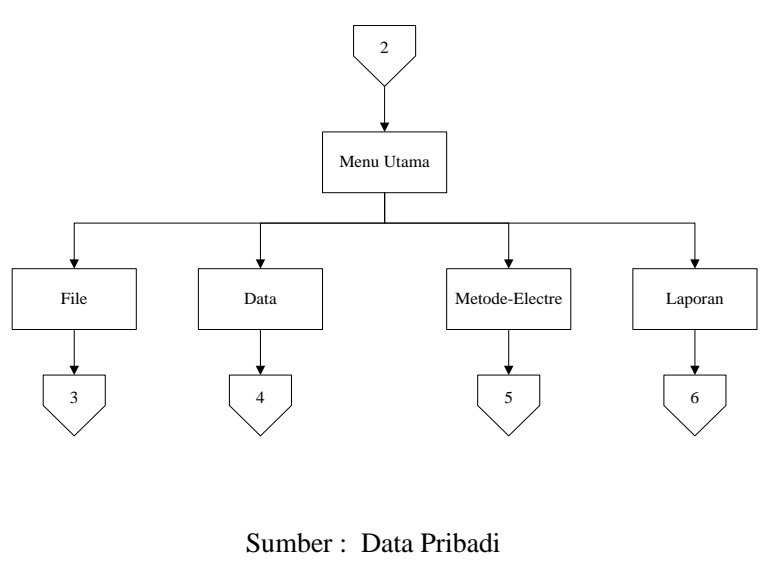

Gambar 3. Flowchart Menu Utama

Pseudocode :

Do pilihan

Pilih = "File" untuk menampilkan isi modul

Pilih = "Data" untuk menampilkan isi modul

Pilih = "Analisa"untuk menampilkan isi modul

Pilih = "Hasil" untuk menampilkan isi modul

End Do

Pada menu utama ini terdapat 4 menu pilihanbagi admin dalam mengolah data sistem yang masing-masing memiliki proses (fungsi) tersendiri. Data keluarannya (output) berupa informasi yang meliputi menu "File" yang berisi tampilan exit, menu "Data" yang berisi form daftar Alternatif dan Data Kreteria, menu "Metode-ELECTRE" yang berisi cara mencari keputusan sehingga menghasilkan suatu hasil akhir/hasil keputusan, menu "Laporan" yang berisi daftar calon penerima Raskin yang dapat dicetak. 


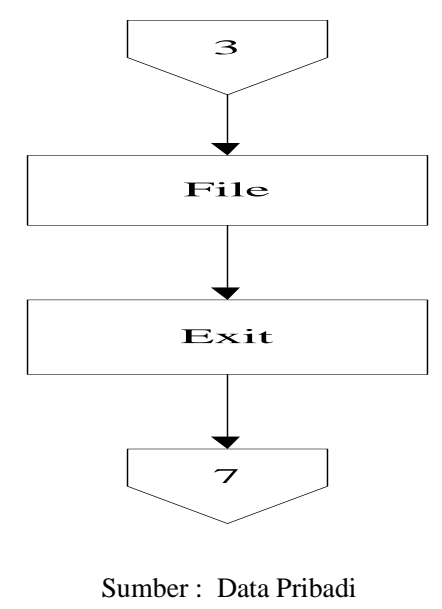

Gambar 4. Flowchart File

Pseudocode :

Tampilkan menu"File“

Do Tampilkan

Tampil "Exit"

End Do

Setelah admin memilih menu "File" yang ditunjukkan dengan nomor 3 (tiga) maka program akan menampilkan menu yang ditunjukkan dengan nomor 7 .

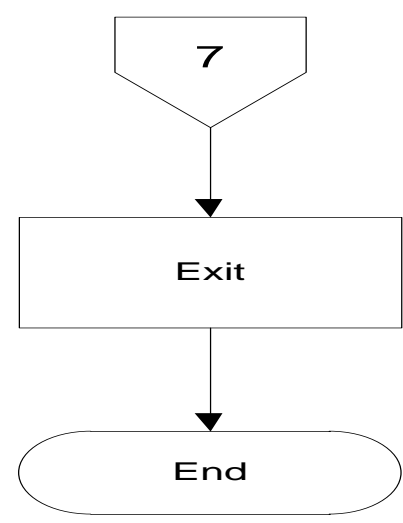

Sumber : Data Pribadi

Gambar 5. Flowchart Exit

Pseudocode:

Proses Exit Aplikasi

Selesai.

Setelah semua proses telah selesai dilakukan maka proses yang terakhir yaitu Exit pada alur nomor 7 (tujuh) yang berfungsi untuk menutup program.

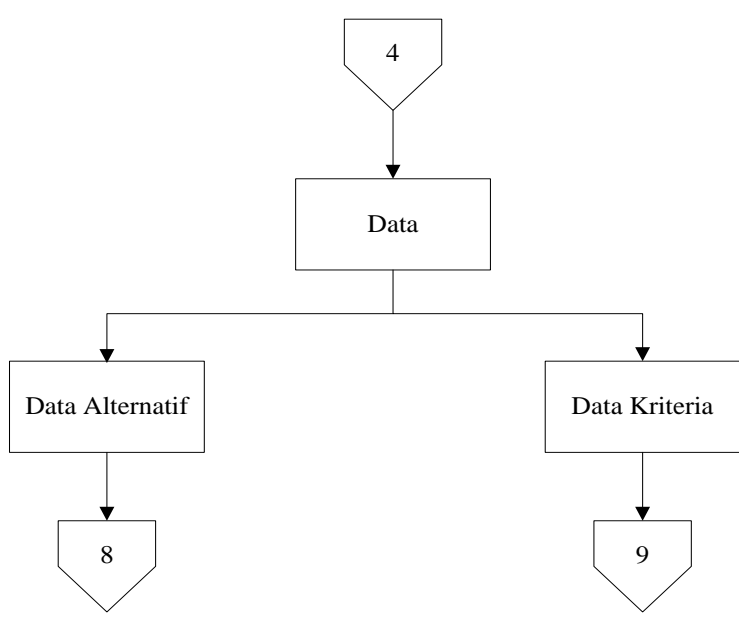

Sumber : Data Pribadi

\section{Gambar 6. Flowchart Manage Data}

Pseudocode :

Tampilkan menu "Data"

Do Tampilkan

Tampil modul"Data"

Do pilihan

Pilih = "Data Alternatif" untuk menampilkan isi modul

Pilih = "Data Kreteria" untuk menampilkan isi modul

End Do

End Do

"Data"

Pada flowchart manage data, ditampilkan dua proses yaitu proses data alternatif dan data kriteria. Data alternative adalah jenis usaha yang akan dipilih user. Sedangkan data kriteria adalah kriteria $7 \mathrm{P}$, yaitu people, promotion, place, physical, product, price, dan process. 


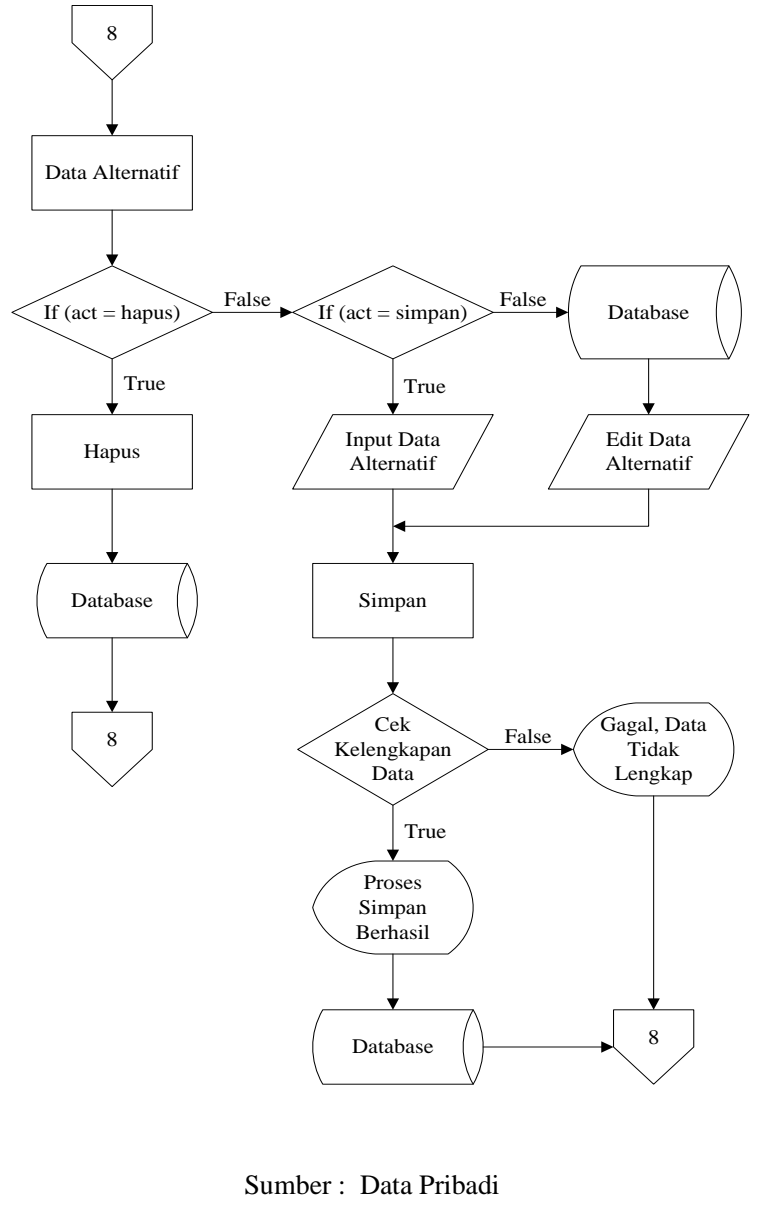

Gambar 7. Flowchart Data Alternatif

Pseudocode :

Tampilkan menu "Data Alternatif" Input data Alternatif

If (act=hapus)

Hapus data Alternatif di

database

Else maka

If $(\mathrm{act}=$ simpan $)$

Input data Alternatif

If data lengkap maka

Tampilkan pesan "Proses

Simpan Berhasil"

End Do

"Daftar Alternatif"

\section{Elsemaka}

Tampilkan pesan "Gagal, Data

Tidak Lengkap"

End Do

"Daftar Alternatif"

Else

Memanggil data dari database
Edit data Alternatif

If data lengkap maka

Tampilkan pesan "Proses

Simpan Berhasil"

End Do

\author{
"Alternatif" \\ Elsemaka \\ Tampilkan pesan "Gagal, Data
}

Tidak Lengkap"

End Do

\section{"Data Altenatif"}

Proses Data Alternatif berisi tentang pengolahan data usaha jasa. Pada menu ini, jika user memilih aksi hapus, penghapusan data langsung menghapus data yang ada dalam database Data Alternatif. Jika user memilih aksi simpan, user harus memasukkan data Data Alternatif, lalu di simpan. Jika data lengkap maka proses simpan berhasil dan menampilkan pesan "Proses Simpan Berhasil". Jika data tidak lengkap maka proses simpan gagal dan menampilkan pesan "Gagal, Data Tidak Lengkap". Untuk perubahan data yang sudah ada, data pada database akan ditampilkan lalu dilakukan perubahan data oleh user. Jika perubahan data yang dimasukkan lengkap maka proses simpan berhasil dan menampilkan pesan "Proses Simpan Berhasil", jika data perubahan tidak lengkap proses simpan gagal dan menampilkan pesan "Gagal, Data Tidak Lengkap". 


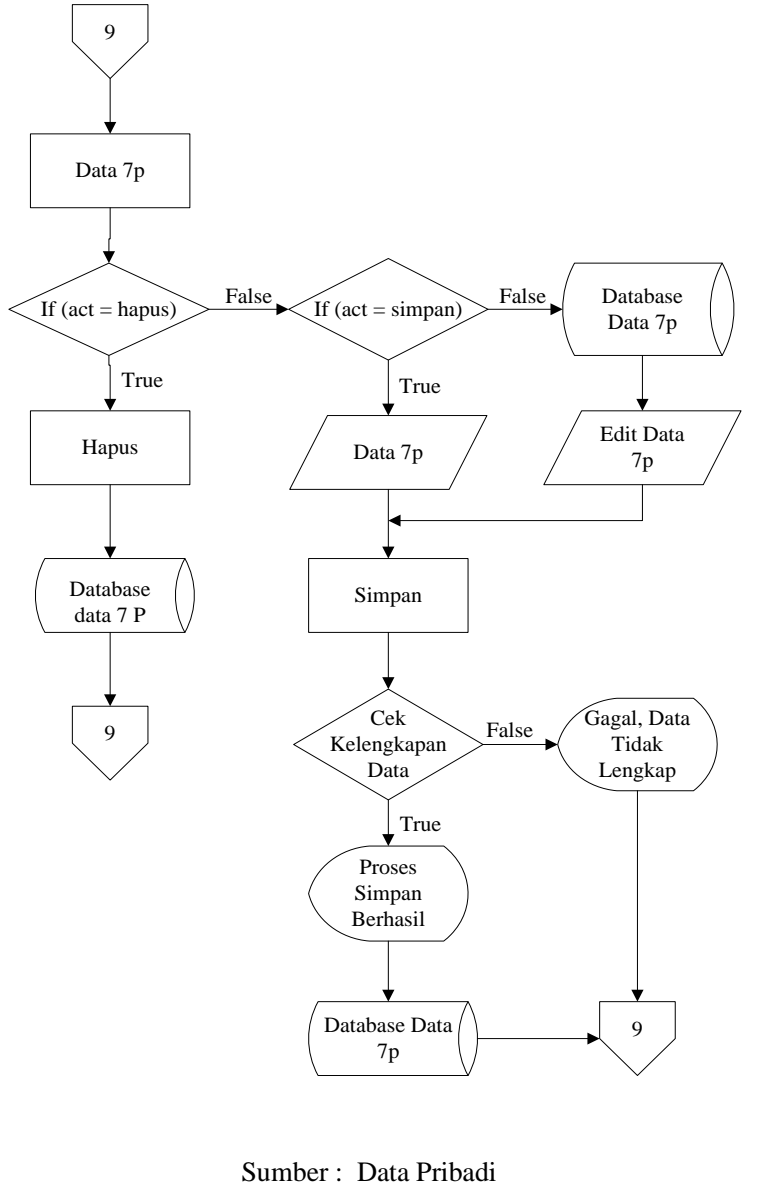

Gambar 8. Flowchart Data Kriteria

Pseudocode :

Tampilkan menu "Data $7 \mathrm{p}$ “

Input Data $7 \mathrm{p}$

If (act=hapus)

Hapus Data $7 \mathrm{p}$ di database

Else maka

If $($ act=simpan $)$

Input Data $7 \mathrm{p}$

If data lengkap maka

Tampilkan pesan "Proses

Simpan Berhasil"

End Do

$$
\text { "Data 7p" }
$$

Elsemaka

Tampilkan pesan "Gagal, Data

Tidak Lengkap"

End Do

$$
\text { "Data 7p" }
$$

Else

Memanggil data dari database Data $7 \mathrm{p}$

Edit Data $7 \mathrm{p}$
If data lengkap maka

Tampilkan pesan "Proses

Simpan Berhasil"

End Do

$$
\text { "Data 7p" }
$$

Elsemaka

Tampilkan pesan "Gagal, Data

Tidak Lengkap"

End Do

$$
\text { "Data 7p" }
$$

Proses Data Kriteria atau Data 7P berisi tentang pengolahan data kriteria pada Electre. Pada menu ini, jika user memilih aksi hapus, penghapusan data langsung menghapus data yang ada dalam database Data 7p. Jika user memilih aksi simpan, admin harus memasukkan data kriteria, lalu di simpan. Jika data lengkap maka proses simpan berhasil dan menampilkan pesan "Proses Simpan Berhasil". Jika data tidak lengkap maka proses simpan gagal dan menampilkan pesan "Gagal, Data Tidak Lengkap". Untuk perubahan data yang sudah ada, data pada database akan ditampilkan lalu dilakukan perubahan data oleh user. Jika perubahan data yang dimasukkan lengkap maka proses simpan berhasil dan menampilkan pesan "Proses Simpan Berhasil", jika data perubahan tidak lengkap proses simpan gagal dan menampilkan pesan "Gagal, Data Tidak Lengkap".

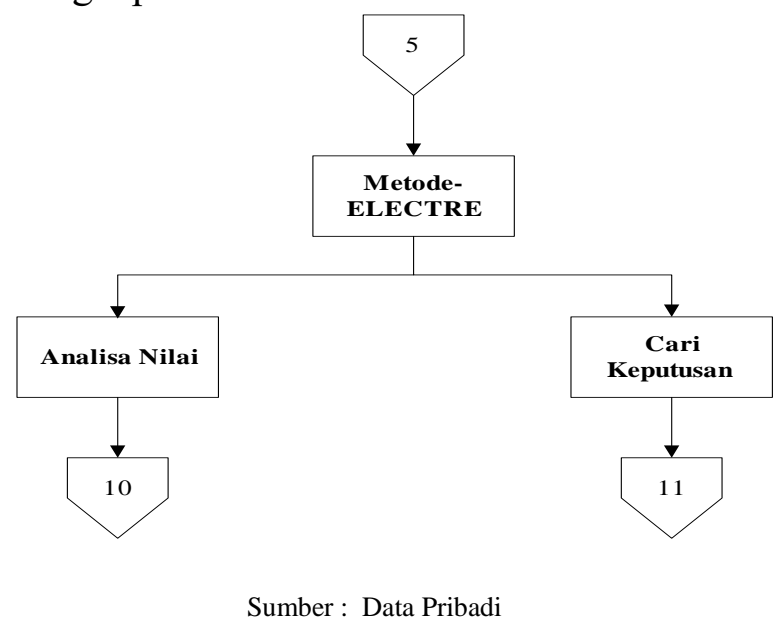

Gambar 9. Flowchart Metode Electre 
Pseudocode :

Tampilkan

menu

"Metode_ELECTRE"

Do Tampilkan

Tampil modul"Metode_ELECTRE " Do pilihan

$$
\text { Pilih = "Analisa Nilai" untuk }
$$

menampilkan isi modul

Pilih = "Cari Keputusan" untuk menampilkan isi modul

End Do

End Do

"Metode_ELECTRE"

Setelah memilih menu Metode_ELECTRE maka program akan menampilakan menu Analisa Nilai dan Cari Keputusan yang berisi tentang nilai kriteria dan cara mencari keputusan.

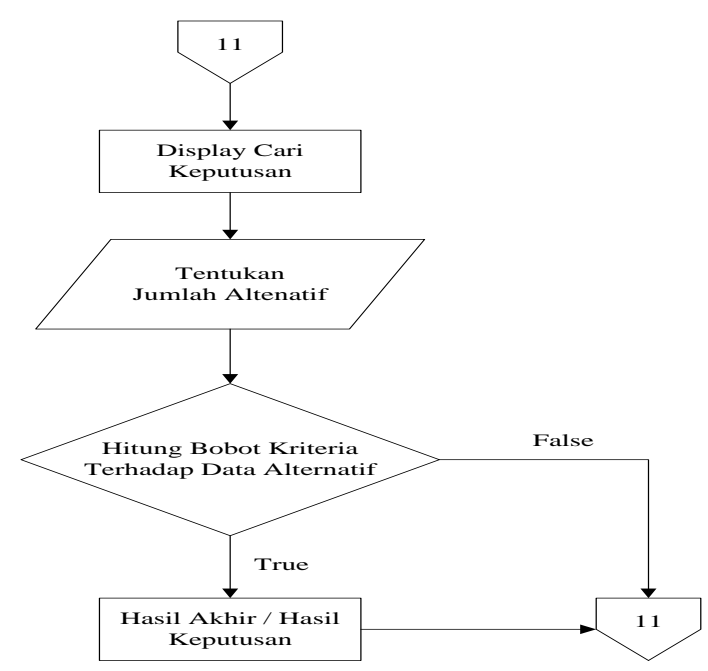

Sumber : Data Pribadi

Gambar 10. Flowchart Pengambilan Keputusan

Pseudocode :

Tampilkan menu "Cari Keputusan" Input data kriteria dan data

Alternatif

If hitung bobot kriteria terhadap data Alternatif cocok

Maka hasil keputusan berhasil didapatkan menampilkan pesan "Hasil Akhir/Hasil Keputusan"

\section{Else maka}

Tampilkan "Hasil Akhir / Hasil Keputusan"

End Do

"Cari Keputusan"

Setelah memilih menu Cari Keputusan maka program akan menampilkan menu Cari Keputusan yang berisi tentang pengolahan data kriteria dan data Alternatif. Pada menu akan melakukan proses perhitungan bobot kriteria terhadap data Alternatif dengan metode Electre.

\section{Tampilan Sistem Pendukung Keputusan}

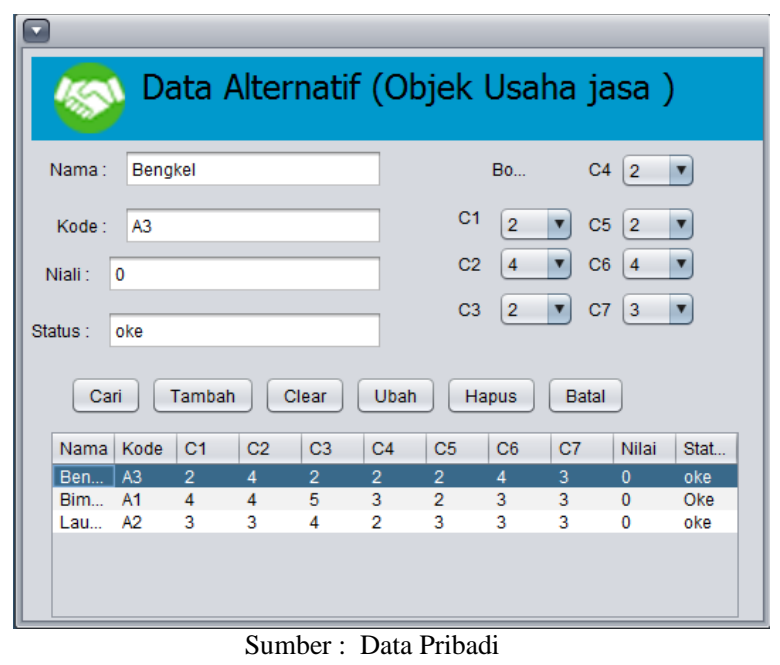

Gambar 11. Tampilan Input Data Alternatif

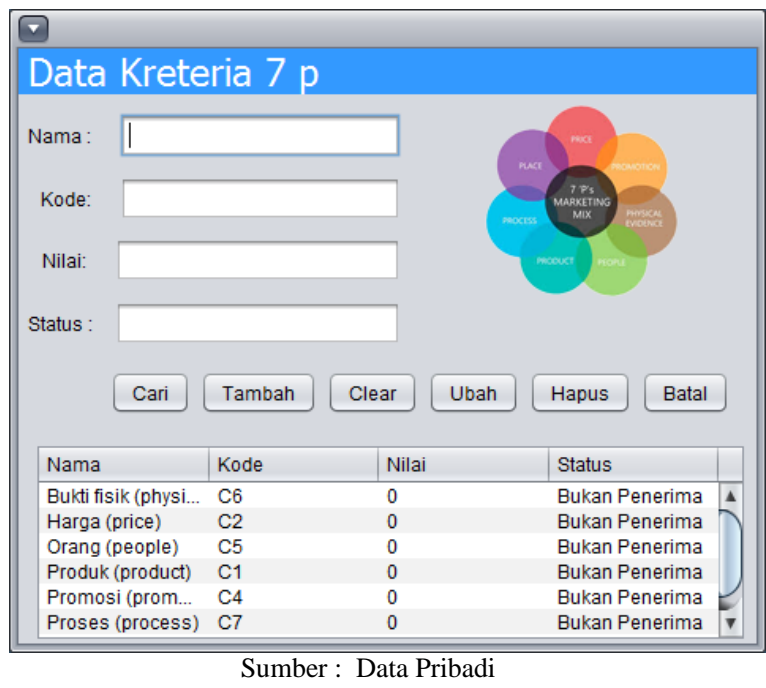

\section{Gambar 12. Tampilan Input Data} Kriteria 


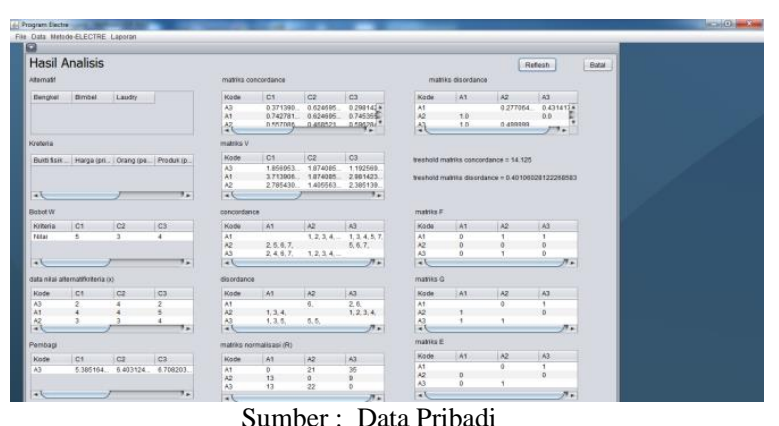

Gambar 13. Tampilan Analisa Nilai

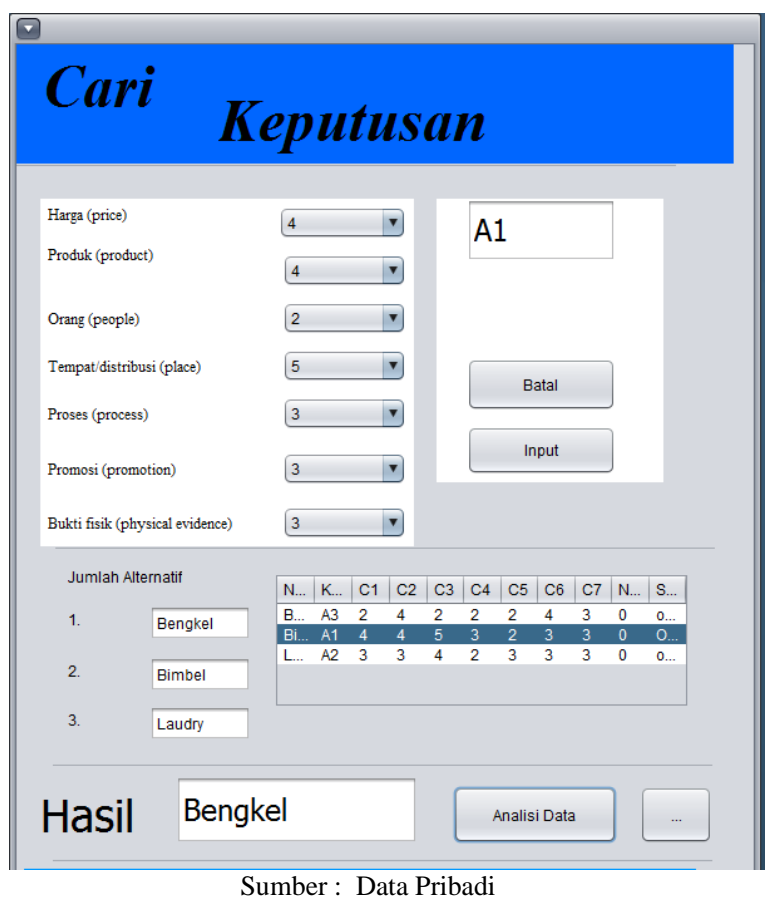

Gambar 14. Tampilan Keputusan

\section{SIMPULAN}

Berdasarkan hasil penelitian yang telah dilakukan, dapat disimpulkan bahwa :

1. Metode Electre dapat digunakan untuk menentukan jenis usaha bagi calon pengusaha.
2. Bauran pemasaran $7 \mathrm{P}$ dapat digunakan sebagai kriteria dalam penentuan jenis usaha bagi calon pengusaha

3. Sistem pendukung keputusan penentuan jenis usaha berdasarkan kriteria 7P menggunakan metode electre dapat membantu calon pengusaha dalam menentukan jenis usaha yang akan dibangun oleh calon pengusaha.

\section{UCAPAN TERIMA KASIH}

Penelitian ini bisa terlaksana atas bantuan dana penelitian dari DPRM DIKTI melalui Kopertis III Jakarta dan Universitas Indraprasta PGRI Jakarta.

\section{DAFTAR PUSTAKA}

[1] Philip Kotler dan Kevin Lane Keller. Manajemen Pemasaran. Edisi Ketiga belas. Jakarta : Erlangga. 2008.

[2] Kusrini. Konsep dan Aplikasi Sistem Pendukung Keputusan.

Yogyakarta : Andi Offset. 2007.

[3] Wolfgang Janko \& Bernoider Edward. Multi-Criteria Decision Making An Application Study of ELECTRE \& TOPSIS Dalam Fuzzy Multi-Attribute Decision Making (MADM). Yogyakarta : Graha Ilmu. 2005.

[4] Haryanto S. Sistem Manajemen Basis Data. Bandung: Informatika. 2004. 